\title{
Strategi Event Public Relations Pada Expo ASESI Dalam Membangun Reputasi Sekolah Sunnah
}

\author{
Rafika Hani \\ Program Studi Public Relations, Fakultas Ilmu Komunikasi, Universitas Mercu Buana Jakarta \\ Email: rafika.hani@mercubuana.ac.id
}

\begin{abstract}
Abstrak
Setiap institusi memahami pentingnya reputasi. Reputasi dibangun melalui strategi-strategi yang disusun secara sistematis oleh sebuah institusi. ASESI sebagai wadah komunikasi sekolah sunnah Indonesia, menyusun strategi komunikasi untuk membangun reputasi sekolah sunnah. Strategi komunikasi yang dilakukan ASESI yaitu dengan mengadakan Expo Pendidikan ASESI. Penelitian ini menggunakan metode kualitatif dengan pendekatan studi kasus. Teknik pengumpulan data dilakukan dengan observasi, wawancara, dan studi pustaka. Hasil dari penelitian ini adalah ASESI melakukan empat proses manajemen strategis dalam melaksanakan Expo. Empat tahapan tersebut terdiri dari tahap definisi masalah dengan menganalisis situasi terhadap fakta dan permasalahan yang terjadi pada sekolah-sekolah sunnah. Tahap perencanaan dan pemograman dilakukan dengan menyusun program strategis dan menetukan konsep baik teknis dan non teknis, serta kooordinasi tugas dan tanggung jawab. Tahap tindakan dan komunikasi dilakukan dengan mengkasifikasi bentuk kegiatan, interaksi secara langsung dengan target khakayak serta publikasi melalui media online dan offline. Tahap evaluasi yaitu membandingkan proses perencanaan dengan tahap pelaksanaan, memonitor pemberitaan di media massa, dan survei jumlah pengunjung

Kata kunci : event, Expo, reputasi, sekolah sunnah, ASESI
\end{abstract}

\begin{abstract}
Each institution have to understands the importance of reputation. The institution constract and compile the reputation with many strategies systematically. ASESI represent as the communication forum for Indonesian Sunnah Schools. ASESI construct the communication strategies to develop the reputation of sunnah schools. ASESI organize an Education Expo as communication strategy. This research use qualitative method by case study approach. Data collection techniques use observation, interviews, and literature study. The result showed that ASESI used four strategic management process to prepared and organized the Expo. The four strategies processes consists of : definition the problem by analyzing situations about facts and problem of sunnah schools. The planning and programming steps are arranging the a strategic plan and deciding the concept for technical and non-technical activities. The actuating and communicating process are, classifying the event, interacting with public directly and publicating in media online and offline. The evaluation are comparating about planning process with the implementation and monitoring the news about Expo and surveying the number of visitors.
\end{abstract}

Keyword : event, Expo, reputation, sunnah school, ASESI

\section{PENDAHULUAN}

Perkembangan dunia pendidikan saat ini mengalami peningkatan yang signifikan. Munculnya berbagai macam tipe sekolah tentunya dapat menjadi referensi bagi orang tua untuk menyekolahkan anak mereka. Saat ini sekolah sunnah menjadi salah yang sudah banyak diminati di kalangan orang tua khususnya umat Muslim. "Sekolah sunnah dan masyarakat Islam yang ingin menyekolahkan putra dan putrinya disekolah Sunnah makin hari terus bertambah. Setiap sekolah sunnah yang baru berdiri biasanya tahun kedua sudah mulai banyak siswanya."(Hasil wawancara dengan Hary, Dewan Pakar ASESI, April 2020).

Persepsi orang tua yang menyekolahkan anaknya di sekolah sunnah saat ini sangat baik. Menurut mereka sekolah sunnah sangat sesuai bagi anak-anaknya untuk mendapatkan pendidikan agama Islam yang ajarannya berlandaskan Al-Qurán dan AS-Sunnah. Saat ini 
sekolah sunnah memiliki citra positif di mata khalayak khususnya orang tua. Berdasarkan penelitian Konstruksi Citra Sekolah Sunnah menurut ASESI, Hani menyatakan bahwa ASESI yang merupakan bagian dari entitas dunia pendidikan menyadari bahwa respon dari khalayaknya terhadap citra sekolah yang dibangun oleh ASESI memiliki respon yang positif dan mendukung eksistensi sekolah sunnah di Indonesia. (Hani, 2019, p.8). Hal ini menjadi nilai tambah untuk membangun reputasi sekolah sunnah itu sendiri.

ASESI (Perkumpulan Komunikasi Sekolah Sunnah Indonesia) merupakan lembaga wadah komunikasi bagi sekolah-sekolah sunnah di seluruh wilayah Indonesia. ASESI mempersepsikan hasil gambaran dan persepsi sekolah sunnah menjadi reputasi yang dapat dibangun. Reputasi sekolah sunnah secara kolektif dikumpulkan untuk menjadi sebuah nilai yang diberikan stakeholders kepada sekolah sunnah. Menurut Watrick dikutip oleh Helm (2007), mengatakan bahwa reputasi adalah gambaran mengenai persepsi dari masing-masing stakeholder tentang seberapa baik perusahaan memberikan respon dalam memenuhi permintaan dan harapan seluruh khalayak. (Ruliana, 2016, pp. 239-240).

Segala upaya dilakukan ASESI untuk tetap menjaga eksistensi sekolah sunnah agar tetap diterima oleh masyarakat. Citra yang sudah terbentuk juga harus dipertahankan sebagai penopang dalam membangun reputasi sekolah sunnah. Sedangkan membangun dan mempertahankan reputasi lembaga itu tidak mudah. Reputasi dibangun dari setiap proses yang bertahap dan perjalanan yang panjang. Seperti yang diungkapkan oleh Trimanah bahwa proses membangun, mempertahankan dan meningkatkan reputasi lebih panjang daripada membangun, mempertahankan dan meningkatkan image dan brand (Trimanah, 2012 , p. 92).

Salah satu hal yang dilakukan ASESI untuk membangun reputasi sekolah sunnah adalah melalui event pameran pendidikan sekolah-sekolah sunnah se-Indonesia yang dinamakan Expo ASESI. Program Expo ini diadakan rutin satu tahun sekali di Jakarta. Expo ASESI ini diselenggarakan dari tahun 2013 dan yang terbaru pada tahun 2019. Expo (exhibitions) merupakan salah satu strategi yang dilakukan praktisi PR sebagai sarana komunikasi kepada publiknya. Hal ini memberikan dampak dan pengaruh terhadap citra dan reputasi sebuah lembaga. "Exhibitions dapat membangun komunikasi eksternal sebuah perusahaan, dengan menanamkan citra yang baik mengenai product, service dan social responsibility kepada masyarakat dapat membangun reputasi sebuah perusahaan."(Jenty dan Setyanto , 2018 , p. 323).

Melalui Expo pendidikan, ASESI memperkenalkan sekolah-sekolah sunnah yang ada di seluruh Indonesia dan menyuguhkan berbagai informasi yang dibutuhkan masyarakat khususnya para orang tua. "Expo sangat berpengaruh terhadap reputasi. Khususnya peningkatan jumlah peminat dan pendaftar sekolah sunnah, sekolah sunnah semakin dikenal. Pengaruh terhadap pengetahuan masyarakat dimana mereka jadi lebih tahu sekolah sunnah yang ada di daerah-daerah."(Hasil wawancara dengan Indra, Ketua ASESI, Maret 2020)

Hasil penelitian terkait pemanfaatan event PR dalam membentuk reputasi institusi sudah dilakukan oleh Jenty dan Setyanto (Jenty dan Setyanto, 2018) dalam Pemanfaatan Event sebagai Upaya Public Relations dalam Membangun Reputasi Perusahaan (Studi pada PT. XYZ sebagai pendukung kegiatan Asian Games 2018). Hasilnya menunjukkan bahwa event dapat membangun reputasi perusahan PT. XYZ dengan data yang didapat dari PR Value dan juga adanya 5G Experience Center yang diquote oleh Presiden Joko Widodo. Namun penelitian ini dilakukan dengan observasi non-partisipan dengan observasi terstruktur. Artinya peneliti tidak langsung terjun ke lapangan untuk melakukan observasi.

Riset lainnya dilakukan oleh Dimyati (Dimyati , 2018) dalam Manajemen Public Relations dan Reputasi Organisasi Lembaga Amil Zakat Dompet Dhuafa. Hasil riset ini menunjukkan bahwa LAZ Dompet Dhuafa tidak melakukan riset khusus terkait perencanaan program; riset yang dilakukan hanya melalui fakta-fakta baru di lapangan melalui program-program yang sudah ada sebelumnya. Perencanaan program tematik dan nontematik LAZ Dompet Dhuafa 
dilakukan melalui rapat kerja tahunan, pesan utama yang ingin disampaikan kepada pihak eksternal disampaikan melalui website resmi dan media sosial. Evalusi program yang dilakukan tidak melibatkan publik eksternal.

Berbeda dengan Rahmayanti (Rhesa Rahmayanti, 2014) mengkaji tentang reputasi perusahaan yang dibangun melalui program lain yaitu Corporate Social Responsibility (CSR) pada PT. KAI (Persero) Daop 6 Yogyakarta. Namun hasil riset ini menunjukkan bahwa program CSR yang dilaksanakan masih berada dalam ranah amal dan pelayanan, bukan perwujudan dari investasi sosial.

Dari beberapa penelitian tersebut, penulis belum menemukan kajian riset yang khusus membahas tentang strategi event $P R$ Expo yang digunakan oleh institusi pendidikan dalam membangun reputasi lembaga pendidikan yang dilakukan melalui observasi dan explorasi langsung ke lapangan. Dalam melaksanakan program Expo nya , ASESI melakukan tahapantahapan strategi yang akan dilakukan untuk keberhasilan program Expo dalam rangka membangun reputasi sekolah sunnah di mata khalayaknya. Berdasarkan penjabaran sebelumnya, maka peneliti bermaksud ingin mengetahui bagaimana strategi event Public Relations berupa Expo yang dilakukan oleh ASESI dalam Membangun Reputasi Sekolah Sunnah.

\section{Manfaat Penelitian}

Manfaat akademis, diharapkan penelitian ini dapat menjadi tambahan referensi dalam kajian bidang ilmu Public Relations yang khusus membahas tentang strategi event $P R$ pada kegiatan Expo dalam membangun reputasi organisasi. Hal ini dikarenakan pembahasan mengenai special event yang berpengaruh dengan reputasi lembaga ini masih sedikit ditemukan, khususnya yang objek kajiannya lembaga pendidikan. Manfaat praktis, diharapkan kajian dari riset ini dapat memberikan manfaat referensi bagi lembaga sekolah dalam mengelola reputasi lembaga melalui kegiatan Expo.

\section{METODE PENELITIAN}

Penelitian ini menggunakan metode kualitatif. Penggunaan metode kualitatif ini bertujuan untuk mendapatkan pemahaman secara komprehensif tentang bagaimana ASESI melihat dan mengamati seacra langsung dalam mempersepsikan faktor apa saja yang penting dilakukan untuk membangun reputasi sekolah sunnah. Pendekatan kualitatif yang digunakan dalam penelitian ini adalah studi kasus dimana peneliti menjabarkan secara komprehensif bagaimana ASESI membangun reputasi sekolah sunnah dengan mengadakan program kegiatan yang diperuntukkan bagi sekolah-sekolah sunnah melalui strategi-strategi komunikasi yang sistematis. Teknik pengumpulan data dalam penelitian ini dilakukan dengan cara observasi, wawancara (interview), dan studi pustaka.

\section{HASIL DAN PEMBAHASAN Hasil Penelitian}

ASESI menyelenggarakan special event yaitu Expo ASESI sebagai solusi mengatasi segala permasalahan yang dihadapi oleh sekolah-sekolah sunnah. ASESI menjadikan Expo ini sebagai sarana sosialisasi dalam memperkenalkan kekhasan dan keunggulan sekolah-sekolah sunnah kepada masyarakat. Expo ini juga diadakan untuk mengeksplorasi minat dan bakat yang ada di dalam ekosistem sekolah sunnah yaitu peserta dan tenaga pendidiknya. Expo ini merupakan pilihan langkah strategis dalam membentuk reputasi sekolahsunnah. Pelaksanaan Expo ASESI ini dilakukan melalui empat tahapan yaitu mendefinisikan masalah, perencanaan dan pemograman, mengambil tindakan dan berkomunikasi, dan mengevaluasi program.

Tahapan pendefinisian masalah dilakukan melaui proses fact finding yang menjadi latar belakang alasan diadakannya Expo. Fakta dimana fenomena hijrah yang sedang berkembang di masyarakat menimbulkan kesadaran para orang tua yang dalam proses berhijrah untuk menempatkan anak-anak mereka di sekolah yang sesuai dengan apa yang mereka pahami saat 
ini. Namun stigma radikalisme, konservatif, dan kaku dari masyarakat menjadi hambatan yang berpengaruh terhadap eksistensi sekolah sunnah, khususnya di daerah-daerah terpencil. Hal ini berdampak pada sulitnya para Ustadz atau yayasan yang ingin mendirikan sekolah sunnah di beberapa daerah.

Minimya pemahaman manajemen pendidikan yang baik, menjadi hambatan lainnya bagi sekolah sunnah untuk dapat berkembang. Selain itu, keterbatasan dana menjadi kendala utama untuk mempromosikan sekolah. Oleh karena itu, Expo perlu dilakukan untuk mempublikasikan keberadaan sekolah sunnah kepada masyarakat dan menghilangkan stigma negatif masyarakat terhadap sekolah sunnah.

Tahap selanjutnya yaitu perencanaan dan pemograman yaitu ASESI menetapkan tujuan kegiatan Expo untuk mempromosikan sekolah-sekolah sunnah yang ada di seluruh wilayah Indonesia. Tujuan kegiatan dituangkan dalam strategi dan taktik yang dapat menarik minat masyarakat untuk hadir di acara tersebut. Kegiatan tersebut antara lain:

1. Pameran lembaga pendidikan Islam bermanhaj Ahlu Sunnah wal Jamaah sebagai sarana sosialisasi dan promosi sekolah sunah.

2. Lomba Musabaqah Hifzul Quran /MHQ Quran antar jenjang pendidikan (SD-SMA) untuk menunjukkan minat dan bakat siswa siswi sekolah sunnah.

3. Seminar pendidikan Islam dalam membantu meningkatkan mutu manajemen pendidikan sekolah sunnah.

4. Seminar Parenting yang berkaitan dengan tema Expo sebagai bentuk dukungan ASESI dan sekolah sunnah dalam meningkatan kualitas orang tua dalam mendidik anak.

5. Sharing session antar lembaga pendidikan yang bertujuan untuk saling memberikan dukungan dan soslusi yang dihadapi sekolah-sekolah sunnah.

Pemilihan media promosi online dan offline serta perencanaan anggaran juga dilakukan pada tahap ini. Pelaksanaan program dilakukan dengan membagi tim kegiatan sesuai fungsi dan tugas masing-masing anggota tim. ASESI juga berkolaborasi dengan Event Organizer Jclouds. Hal ini dilakukan untuk mempermudah kinerja kepanitiaan Expo.

Tahap ketiga yaitu tindakan dan komunikasi kegiatan Expo. Dalam tahap tindakan, strategi dilakukan dengan membagi kegiatan menjadi tiga fase yaitu Soft Opening, Grand Opening, dan Closing. Soft Opening dan Grand Opening dimulai hari Kamis sampai Sabtu, sedangkan Closing diadakan pada hari Minggu. Hal ini dilakukan untuk menyesuaikan waktu aktifitas dari kegiatan target sasaran, dimana hari kerja kecenderungan pengunjung untuk datang masih sedikit karena aktifitas rutin seperti bekerja dan sekolah.

Tahap komunikasi dilakukan dengan menyampaikan informasi Expo kepada masyarakat dengan terpaan informasi secara terus menerus melalui media publikasi online dan offline. Dalam upaya mewujudkan pelayanan yang maksimal, Expo ini menyediakan media center sebagai pusat informasi yang dibutuhkan awak media dan pengunjung. Pada pelaksanaanya, ASESI tetap berpegang teguh pada prinsip-prinsp dakwah Ahlusunnah dan konsep Expo pendidikan ilmiah yang mengedepankan dakwah melalui pesan-pesan yang disampaikan baik dalam seminar, pameran pendidikannya, dan informasi- informasi lainnya. Hal ini ditujukan agar tetap memberikan kesan mendalam bagi pengunjung, bahwa Expo tersebut merupakan perwujudan kepedulian ASESI dalam mengemban dakwah As-Sunnah dalam bidang pendidikan kepada masyarakat. Strategi lainnya yaitu dengan mengundang public figure di Opening dan Closing. Hal ini bertujuan agar Expo dapat dikenal lebih luas oleh masyarakat umum dan untuk menarik minat media agar meliput kegiatan Expo.

Evaluasi dilakukan dua minggu hingga satu bulan setelah Expo. Hal-hal yang dievaluasi adalah mengidentifikasi kendala-kendala yang dihadapi selama Expo, menganalisis penuruan atau peningkatan peserta Expo, dan melihat perbandingan rasio lembaga pendidikan dan non pendidikan yang hadir. Inti dari evaluasi yang dilakukan yaitu menekankan pada kinerja input; kinerja proses; kinerja output; dan kinerja dampak dari Expo. Hasilnya Expo yang diadakan 
ASESI mengalami peningkatan baik dari segi jumlah peserta pameran dan pengunjung yang datang.

Monitoring juga dilakulan pada tahap ini melalui pemberitaan yang ditampilkan di media massa cetak maupun elektronik terhadap kegiatan Expo. Hasilnya yaitu keterlibatan media massa nasional masih sangat minim dalam memberitakan Expo ini. Pada evaluasi pembentukan kepanitiaan dan perencanaan Expo selanjutnya juga dilakukan.

Gambar 1: Media Publikasi Expo
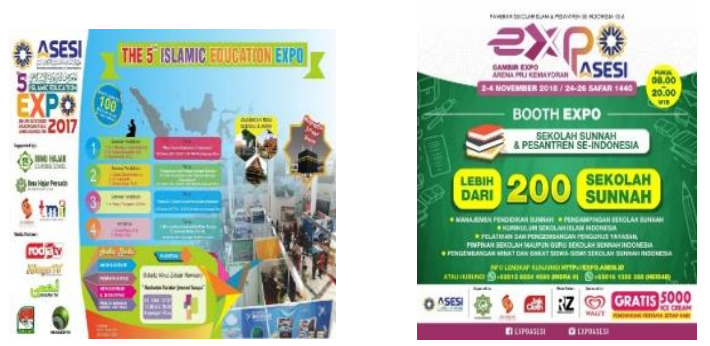

Gambar 2 : Expo ASESI
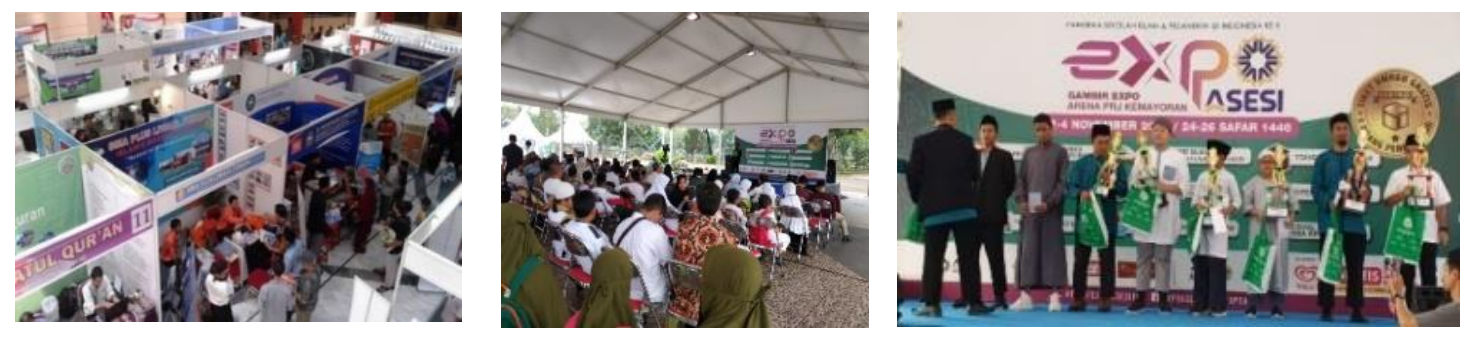

\section{Pembahasan}

Reputasi merupakan nilai penting bagi sebuah institusi yang dibangun dengan jangka waktu dan proses yang panjang. Reputasi merupakan akumulasi dari persepsi publik perusahaan baik internal maupun eksternalnya. Dalam membangun reputasi perusahaan melakukan interaksi dengan publiknya. Menurut Husni, reputasi adalah identitas dan citra yang dibangun dalam waktu lama dan telah tahan uji dalam jangka panjang hasil interaksi atau strategi komunikasi perusahaan dalam berinteraksi dengan publik, target, sasaran atau konstituen perusahaan (Husni , et al, 2017,p. 100). ASESI menyelenggarakan kegiatan Expo yang diadakan dari tahun 2013 hingga tahun 2019. Hal ini menandakan adanya upaya yang dilakukan ASESI dalam membangun reputasi sekolah sunnah melalui proses dan jangka waktu yang cukup lama.

Proses membangun reputasi dapat dilakukan melalui beberapa strategi komunikasi, salah satunya special event yaitu Expo. Lidia menyatakan bahwa pameran adalah event masyarakat yang diselenggarakan oleh suatu organisasi independen dan terbuka untuk umum. Ini menunjukkan bahwa pameran digunakan oleh perusahaan sebagai salah satu media komunikasi langsung tatap muka antara pihak perusahaan dengan publiknya (Evelina, 2005, p.4). ASESI mengadakan special event berupa Expo dalam berskala besar yang di dalamnya terdapat interaksi langsung antara sekolah-sekolah sunnah dengan publiknya. Keberadaan Expo ASESI ini direalisasikan sebagai bentuk strategi komunikasi dalam mensosialisasikan sekolah sunnah kepada masyarakat. Demi mewujudkan keberhasilan pelaksanaan Event Expo ini, ASESI merealisasikannya berdasarkan strategi empat langkah proses dalam $P R$ yang diungkapkan oleh Cutlip dkk (Cutlip, et al, 2009) yang terdiri dari mendefinisikan masalah, perencanaan dan pemograman, mengambil tindakan dan berkomunikasi, dan mengevaluasi program. (Cutlip, et al, 2009, p.320). 
Tahap pertama yang dilakukan yaitu pendefinisian masalah. Hasil analisis yang menyatakan bahwa kurangnya dana untuk promosi dan stigma negatif dari masyarakat menunjukkan minimnya pemahaman sistem manajeman pendidikan yang dialami hampir sebagian besar manajemen sekolah sunnah. Faktor ini akan berdapampak pada mutu pelayanan dan kualitas dari lembaga itu sendiri dan berpengaruh terhadap reputasi di tengah daya saing perkembangan lembaga pendidikan di Indonesia. Menurut Hidayat, dalam situasi lingkungan yang penuh dengan dinamika ini, manajemen pendidikan harus dapat menciptakan organisasi yang dapat memberikan pelayanan yang memuaskan kepada masyarakat pada umumnya dan objek pendidikan (siswa dan orangtua) pada khususnya (Hidayat,2013, p. 187). Dengan melakukan tahapan definisi masalah ini, ASESI menemukan fakta-fakta yang digunakan sebagai latar belakang pelaksanaan Expo. Alasan dilaksanakannya Expo yaitu sebagai solusi bagi sekolah sunnah dalam untuk mensosialisasikan dan mempublikasikan sekolah kepada masyarakat.

Tahap kedua yaitu, perencanaan dan pemograman (planning and programming) yang diawali dengan penetapan tujuan, target sasaran, waktu, tempat pelaksanaan dan pengalokasian biaya yang digunakan. "Perencanaan dan pemograman. Infomasi yang dikumpulkan dalam langkah pertama digunakan untuk membuat keputusan tentang program publik, strategi tujuan, tidakan dan komunikasi, taktik, dan sasaran." (Cutlip,et al, 2009, p. 320)

Berdasarkan elemen-elemen tersebut ASESI menyusun perencanaan dan pemograman secara strategis dan taktis yang disesuaikan dengan kebutuhan target khalayak internalnya dan eksternalnya. Hal ini dilakukan agar keseluruhan pesan dalam Expo tepat sasaran. Seperti yang dinyatakan oleh Dimyati bahwa efektivitas dalam proses komunikasi perlu dilakukan melalui proses manajemen terpadu, terarah, dan tepat sasaran. Manajemen harus mampu memaksimalkan pengelolaan sumberdaya komunikasi yang ada untuk meningkatkan kualitas dan efektivitas pertukaran pesan dalam berbagai konteks komunikasi (individual, organisasional, governmental, sosial, atau internasional). (Dimyati, 2018 ,p.168).

Implementasi program dilakukan dengan berkolaborasi bersama Event Organizer. Pengkoordinasian disusun dengan membagi tugas-tugas sesuai dengan tim setiap acara. Hal ini mengindikasikan bahwa Expo ini menggunakan Struktur event organizer terfokus pada program. Menurut Noor dalam Manajemen Event (Noor, 2009,p.125), struktur ini membagi panitia pelaksana menjadi sub-sub bagian sesuai dengan bidang dan kerjanya masing.

Gambar 3 : Struktur event organizer yang fokus pada program

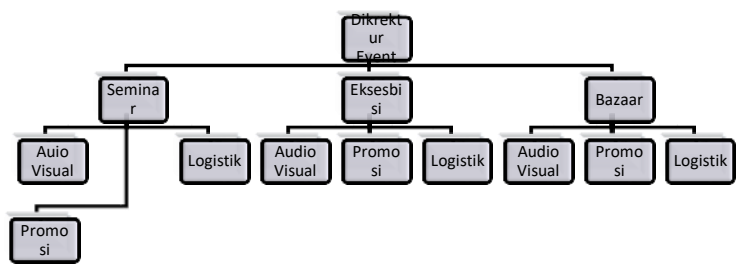

Penggunaan struktur event organizer ini dimaksudkan untuk memudahkan alur komunikasi antara tim anggota pelaksana sesuai tanggung jawabnya. Proses perencanaan dan pemograman yang matang, dapat menjadi peluang besar keberhasilan bagi pelaksanaan program Expo.

Tahap ketiga yaitu tindakan dan komunikasi. Pada Expo ini, strategi dan taktik disusun dengan membagi tiga konsep fase kegiatan yang bertujuan agar program yang direncanakan dan pesan yang ingin disampaikan tepat sasaran sesuai target khalayaknya. "Langkah ketiga adalah mengimplementasikan program aksi dan komunikasi yang didesain untuk mencapai tujuan spesifik untuk masing-masing publik dalam rangka mencapai tujuan program" (Cutlip, et al,2009, p.320). Penyampaian pesan yang tepat pada proses tindakan akan berdampak pada efektifitas pesan yang diterima. 
Tahap tindakan lainnya dilakukan dengan interaksi dengan pengunjung melalui penyampaian pesan-pesan berupa informasi produk dan layanan dari sekolah sunnah. Proses ini menghasilkan interaksi langsung antara sekolah sunnah dengan khalayaknya. Keterbukaan informasi yang diperoleh dari kedua pihak terjadi saat interaksi itu berlangsung. Persepsi dan kesan pengunjung diperoleh berdasarkan pengalaman dalam interaksi tersebut.

Penyampaian pesan dalam seminar keislaman dan lomba-lomba membaca Al- Qurán yang diselenggarakan dapat memberi atmosfir dakwah islam yang menjadi pengalaman bagi para pengunjung. Seperti yang diungkapkan Mansur dan Ali bahwa Public Relations need to let customer involve (Customer Engagement) with the company to create a unique experience. (Mansur and Ali,2017, p.426). Pengalaman unik ini dapat menimbulkan kesan serta persepsi para pengunjung. Menurut Husni dkk, reputasi terbentuk sebagai hasil rangkaian pengalaman langsung. Dan pengalaman itu tidak hanya saat publik berinteraksi melalui perantaraan media seperti membaca koran, menonton televisi atau mengikuti sebuah pameran. Tapi juga pada saat mereka membeli produk atau jasa, bahkan saat mereka bertemu dengan karyawan-karyawan perusahaan." (Husni , et al, 2017,p. 90). Konsistensi ASESI dalam program dakwah pendidikan keislaman melalui Expo ini dapat membentuk pengalaman dan persepsi pengunjung yang menjadi nilai komponen dalam membangun reputasi sekolah sunnah.

Tahap komunikasi dilakukan dengan memberikan terpaan informasi secara terus menerus melalui publikasi media online dan offline terkait kegiatan Expo. Seperti yang diungkapkan oleh Lestari dan Nurhajati bahwa, Public Relations harus mempergunakan saluran media informasi yang tepat dan terpercaya serta dipilih oleh khalayak sebagai target sasaran (Lestari dan Nurhajati, 2019,p. 13). Pemilihan dan pemanfaatan media publikasi yang tepat akan berpengaruh besar terhadap efektifitas penyampaian informasi Expo kepada masyarakat.

Pada tahap ini juga, public figure dipilih sebagai narasumber pesan dalam mendukung kegiatan Expo. Hal ini menjadi strategi yang tepat untuk dapat menarik minat pengunjung dan media. Tulung (2007) dalam Kurniawan dkk. mengatakan bahwa Public figure diundang sebagai narasumber, lebih karena nilai jual sebagai Public figure yang memiliki daya tarik tersendiri. (Kurniawan dan Ashfahani, 2018, p.130). Dengan mengundang public figure sebagai salah satu pembicara dalam Expo dapat menjadi nilai tambah terhadap isi pesan yang disampaikan, karena public figure dianggap memiliki kredibilitas sesuai bidangnya.

Tahapan terakhir yaitu evaluasi yang dilakukan berdasarkan pada konsep dan program yang direncanakan. Penilaian dilakukan dengan mengkomparasi sejauh mana perencanaan dan pemograman berhasil diimplementasikan secara tepat pada saat Expo berlangsung. Monitoring berita juga menjadi pilihan dalam evaluasi Expo ini. "Sebuah sistem monitoring dan evaluasi harus dinyatakan dengan jelas berdasarkan pada tujuan dan rencana kerja organisasi dan selanjutnya dapat digunakan sebagai standar untuk mengukur kemajuan." (Purba, 2019,p.30).

Hasil evaluasi monitoring dimana masih minimnya pemberitaan di media massa tentang Expo menjadi tugas besar bagi ASESI, karena media massa menginformasikan segala sesuatu yang berkaitan dengan organisasi. Hal ini dapat memberikan dampak yang besar terhadap reputasi lembaga. Menurut Nurdiansyah, peran media massa dalam pembentukan reputasi tergantung dari berita yang dipublikasikan. Media massa sangat penting untuk mempublikasikan segala bentuk informasi (Nurdiansyah, As'ari dan Kartika, 2020, p.50). Dengan adanya pemberitaan Expo ini di media massa dapat memberikan pengaruh besar terhadap penilaian masyarakat berdasarkan informasi yang ada di media massa tersebut.

Respon peserta juga dapat dievaluasi melalui penilaian jumlah pengunjung dan peserta Expo yang ikut serta. "Evaluasi dapat dilakukan di setiap fase atau dilakukan secara menyeluruh. Kegiatan dapat dilakukan dengan menggunakan survei kepuasan dan melakukan pencatatan berapa jumlah peserta dan pengunjung." (Goldblatt,2002,pp. 36-55). Melalui pencatatan jumlah peserta dan pengunjung yang datang dapat menjadi acuan sejauh mana 
masyarakat menerima informasi terkait Expo. Melalui metode evaluasi yang tepat akan menjadi pedoman bagi pelaksanaan Expo ASESI selanjutnya.

Education Expo menurut ASESI menjadi sebuah solusi dari permasalahan dihadapai manajemen sekolah sunnah. Penerapan manajemen pendidikan yang kurang baik akan berpengaruh pada reputasi sekolah sunnah. Oleh karena itu, dalam membangun reputasi sekolah sunnah melalui Expo, ASESI melakukan implementasi proses empat langkah strategi PR yaitu terdiri dari proses, mendefinisikan problem, perencanaan dan pemograman, mengambil tindakan dan berkomunikasi, dan mengevaluasi Program.

Strategi empat langkah ini berpengaruh pada pembentukkan reputasi sekolah sunnah. Menurut Ananto yang dikutip oleh Husni (Husni,et al,2017,p.100), ada beberapa faktor elemen penting yang membentuk reputasi.

Gambar 4 : Faktor Pembentukan Reputasi

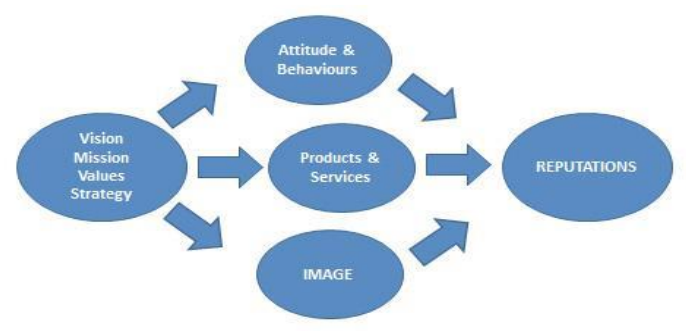

Faktor-faktor di atas menjadi elemen penting dalam pembentukan reputasi sekolah sunnah. Faktor berupa visi, misi, nilai dan strategi direalisasikan melalui konsistensi ASESI dalam membantu sekolah-sekolah sunnah dalam meningkatkan mutu pendidikan yang berkualitas dan berdaya saing melalui program-program Expo. Produk dan jasa dari sekolah sunnah ditawarkan pada penyelenggaraan Expo. Perilaku dari sumber daya manajemen sekolah sunnah dapat dimanifestasikan dalam interaksi antara pengunjung dengan booth stand sekolah-sekolah sunnah yang dapat menimbulkan citra lembaga.

Penjabaran di atas menunjukkan bahwa ASESI menjalankan fungsi PR untuk membentuk reputasi sekolah sunnah. Jenty dan Setyanto menyatakan bahwa peran seorang public relations memiliki ruang lingkup yang salah satunya sebagai penyelenggaran events melalui aktivitas yang ada, salah satunya adalah event management, exhibitions dapat membangun komunikasi eksternal sebuah perusahaan dengan menanamkan citra yang baik mengenai product, service dan social responsibility kepada masyarakat dapat membangun reputasi sebuah perusahaan. (Jenty dan Setyanto ,2018,p.323). Dalam hal ini, ASESI mengadaptasi strategi PR yang diimplementasikan dalam bentuk Expo sebagai salah satu langkah dalam membangun reputasi sekolah sunnah.

\section{KESIMPULAN DAN SARAN}

\section{Kesimpulan}

Reputasi merupakan nilai penting yang dimiliki dan dibangun dengan proses dan waktu yang panjang oleh sebuah institusi. ASESI mengadakan special event Expo yang dimulai pada tahun 2013 sampai 2019. Berdasarkan hasil penelitian dapat disimpulkan bahwa ASESI melewati proses dengan jangka waktu panjang untuk membangun reputasi sekolah sunnah. Sebagai strateginya, ASESI menggunakan empat langkah manajemen PR.

Tahap pertama yaitu definisi masalah yang dilakukan dengan menganalisis situasi terhadap fakta dan permasalahan yang dihadapi sekolah-sekolah sunnah. Tahap perencanaan dan pemograman dilakukan dengan menyusun program strategis, menetukan konsep teknis dan non teknis, serta kooordinasi tugas dan tanggung jawab. Tahap tindakan dan komunikasi dilakukan dengan mengklasifikasi bentuk kegiatan, interaksi secara langsung dengan target 
khalayak serta publikasi melalui media online dan offline. Tahap evaluasi yaitu membandingkan proses perencanaan dengan tahap pelaksanaan, monitoring pemberitaan di media massa, dan survei jumlah pengunjung. Namun, pada tahap ini ditemukan hambatan berupa kurangnya pemberitaan di media massa nasional. Hal ini menjadi catatan besar bahwa media relations yang dilakukan ASESI masih perlu dikaji kembali, karena peran media cukup besar dalam membentuk reputasi lembaga.

Selain itu, indikator faktor-faktor pembentuk reputasi yang dinyatakakan oleh Ananto (Husni, et al, 2017) terealisasi melalui program Expo. Sehingga dapat dinyatakan bahwa proses membangun reputasi sekolah sunnah oleh ASESI diimplementasikan dengan baik melalui special event yaitu Expo.

\section{Saran}

Penelitian yang membahas implementasi strategi PR khususnya sepcial event dalam membangun reputasi institusi pendidikan masih sedikit ditemukan. Oleh karena itu, saran akademisnya bahwa penelitian ini dapat dikembangkan melalui kajian pada lembaga pendidikan yang lain sebagai tambahan khasanah di bidang komunikasi pendidikan khususnya yang membahas strategi $P R$.

Sisi praktisnya, saran bagi ASESI Expo ini sangat bermanfaat dalam membangun reputasi sekolah sunnah, oleh karena itu pelaksanaan Expo ini sebaiknya dilakukan dengan tetap mengadaptasi strategi komunikasi yang tepat. Selain itu keterlibatan media massa nasional $\begin{array}{llll}\text { perlu ditingkatkan } & \text { kembali } & \text { oleh }\end{array}$

\section{DAFTAR PUSTAKA}

Budiman Purba, Eddy Iskandar \&. Suardi. 2019. "Model Perencanaan Komunikasi Pemerintah Kecamatan Padang Tualang Dalam Pemberdayaan Ekonomi Kerakyatan." Jurnal Warta Edisi : 61 Juli 2019 / ISSN : 1829-7463 61:19-33.

Cutlip, Scott M, Center, Allen H and Broom, Glen M. 2009. Effective Public Relations. Edisi Kese. Jakarta: Kencana.

Dimyati, Ahmad. 2018. "Manajemen Public Relations Dan Reputasi Organisasi Lembaga Amil Zakat Dompet Dhuafa." Nyimak (Journal of Communication) 2(2):167-85. doi: 10.31000 /nyimak.v2i2.860.

Evelina, Lidia. 2005. Event Organizer Pameran. Jakarta: PT. Indeks Gramedia.

Goldblatt, Joe. 2002. Special Events : Third Edition. Third edit. New York: John Wiley and Sons.

Hani, Rafika. 2019. "Konstruksi Citra Sekolah Sunnah Di Indonesia (Studi Kasus Konstruksi Citra Sekolah Sunnah Menurut Perkumpulan Komunikasi Sekolah Sunnah Indonesia (ASESI)." Jurnal Ilmu Komunikasi 7(2).

Hidayat, Rahmat. 2013. "Pengaruh Manajemen Strategik Dan Biaya Pendidikan Terhadap Daya Saing Sekolah Di Sekolah Dasar Negeri Se-Kecamatan Mangkubumi Kota Tasikmalaya." Jurnal Ilmiah Mahasiswa Pascasarjana Administrasi Pendidikan I(2):187-92.

Husni , Mochamad, Rachmawati Sugiyanto , Dyah dan Nurnisya, Frizki. 2017. Reputasi Yang Berkarakter. Jakarta: Media Piar Indonesia.

Jenty, Feberi, dan Yugih Setyanto. 2018. "Pemanfaatan Event Sebagai Upaya Public Relations Dalam Membangun Reputasi Perusahaan (Studi Pada PT. XYZ Sebagai Pendukung Kegiatan Asian Games 2018)." Prologia 2(2):320. doi: 10.24912/pr.v2i2.3593.

Kurniawan, Arifin Hendri, dan Shulhuly Ashfahani. 2018. "Peran Narasumber Dalam 
Keberlangsungan

Inspirasi Pag

Di JAK TV

Tahun

2016."

Jurnal Ilmiah

Komunikasi (JIKOM) STIKOM IMA 10(03):128. doi: 10.38041/jikom1.v10i03.37.

Lestari, Hessy, dan Lestari Nurhajati. 2019. "Strategi Public Relations Untuk Menciptakan Minat." JURNAL LONTAR VOL.7 NO.1 JANUARI-JUNI 2019 7(1):9-15.

Mansur, Suraya, and Hapzi Ali. 2017. "Impact of Customer Engagement to Reputation of the Bri Syariah Indonesia." International Journal of Economic Research 14(19):425-31.

Noor, Ani. 2009. Manajemen Event. Cetakan-1. Bandung: Alfabeta.

Nurdiansyah, As'ari; Kartika, Risma. 2020. "Penerapan Media Relations Dalam Mempertahankan Reputasi Kementerian Pertanian Republik Indonesia." Ekspresi Dan Persepsi : Jurnal Ilmu Komunikasi, FISIP UPN VETERAN 3(1):48-57.

Rhesa Rahmayanti, Dian. 2014. "Implementasi Corporate Social Responsibility Dalam Membangun Reputasi Perusahaan." Jurnal ILMU KOMUNIKASI 11(1):93-104. doi: 10.24002/jik.v11i1.387.

Ruliana, Poppy. 2016. Komunikasi Organisasi : Teori Dan Studi Kasus. Edisi Kedu. Depok: Raja Grafindo Persada.

Trimanah. 2012. "Reputasi Dalam Kerangka Kerja Public Relations." Jurnal Ilmiah Komunikasi 3(1):92-102.

Tulung, Sony. 2007. Anda Juga Bisa Jadi Presenter Tv Sukses! Jakarta: Elex Media Komputindo. 